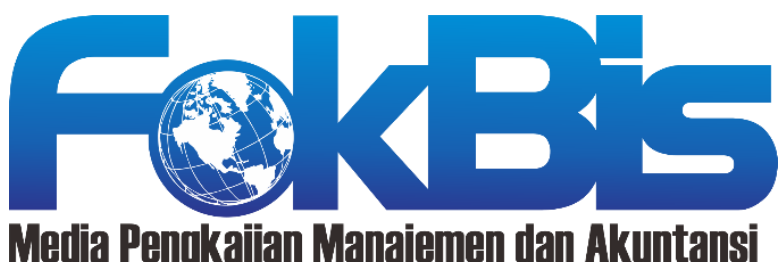

http://journal.stieputrabangsa.ac.id/index.php/fokbis/index

ISSN: 2623-2480/ P-ISSN: 1693-5209

\section{Peran Modal Intelektual dalam Memoderasi Risiko Investasi dan Struktur Modal Terhadap Nilai Perusahaan pada Perusahaan Manufaktur Sub Sektor Makanan dan Minuman Yang Terdaftar di Bursa Efek Indonesia}

\author{
Susanti Widhiastuti ${ }^{1}$, Bilqis Zamzamiria Putri Sukarya ${ }^{2}$, Slamet Ahmadi ${ }^{3}$ \\ 1,2,3)STIE IPWIJA \\ email: santiwidhiastuti@gmail.com ${ }^{1}$
}

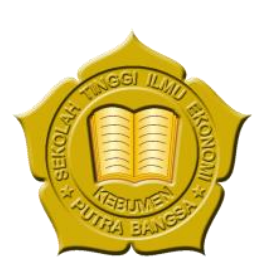

Article Information

\author{
History of Article: \\ Received October 30th 2020 \\ Accepted December 23 2020 \\ Published December $31^{\text {st }} 2020$
}

\section{DOI:}

10.32639/fokusbisnis.v19i2.731

\begin{abstract}
ABSTRAK
Penelitian ini bertujuan untuk menguji peran modal intelektual dalam memoderasi risiko investasi dan struktur modal terhadap nilai perusahaan. Modal Intelektual diukur dengan value added intellectual capital coefficient (VAIC), Risiko investasi diukur menggunakan standar deviasi (SD) dan struktur modal diukur dengan menggunakan debt to equity ratio (DER) dan nilai perusahaan diukur menggunakan price to book value (PBV). Populasi dalam penelitian ini adalah perusahaan manufaktur.Tbk yang terdaftar di Bursa Efek Indonesia (BEI) periode 2017-2018 sub sektor makanan dan minuman. Sampel penelitian berjumlah 12 perusahaan. Metode sampel menggunakan purposive sampling. Hasil penelitian menunjukkan bahwa $\mathrm{R}$ Square sebelum adanya moderasi peran modal intelektual, struktur modal dan resiko investasi terhadap nilai perusahaan memberikan masukan sebesar $24,6 \%$ dan pada saat modal intelektual memoderasi struktur modal terhadap nilai perusahaan dan resiko bisnis terhadap nilai perusahaan $\mathrm{R}$ square sebesar $25,8 \%$. Hasil penelitian model tanpa moderasi menunjukkan bahwa modal intelektual berpengaruh positif signifikan sebesar $25 \%$, resiko investasi berpengaruh negative signifikan sebesar -1,063 dan struktur modal berpengaruh negative tidak signifika sebesar $-2,121$ terhadap nilai perusahaan. Peran modal intelektual dalam memoderasi resiko invesatasi dengan nilai perusahaan berpengaruh positif tidak signifikan sebesar $40,1 \%$ dan antara struktur modal dengan nilai perusahaan berpengaruh negative dan tidak signifikan sebesar $-52,7 \%$.
\end{abstract}

Kata Kunci: Modal Intelektual; Resiko Investasi; Struktur Modal; Nilai Perusahaan

\begin{abstract}
This study aims to analyze the role of intellectual capital in moderating investment risk and capital structure on firm value. Intellectual capital is measured by The Value-Added Intellectual Capital Coefficient (VAIC), investment risk is measured by standard deviation (SD) and capital structure is measured by the Debt to
\end{abstract}


Equity Ratio (DER) and company value is measured by the Price to Book Value (PBV). The population in this study were manufacturing companies listed on the Indonesian Stock Exchange (IDX) in 2017-2018 period of the food and beverage sub-sector. The sampling of this research, consisted of 12 companies. The sampling method using purposive sampling. The results showed that the $R$ Square before moderating the role of intellectual capital, capital structure, and investment risk on firm value gave input of $24.6 \%$. Compared after moderated, $R$ square was $25.8 \%$. The results of the research model without moderation show that intellectual capital has a significant positive effect of $25 \%$, investment risk has a significant negative effect of -1.063 and capital structure has a negative and insignificant effect of -2,121 on firm value. The role of intellectual capital in moderating investment risk with firm value has a positive and insignificant effect of $40.1 \%$ and between capital structure and firm value has a negative and insignificant effect of $-52.7 \%$.

Keywords: Intellectual Capital, Investment Risk, Capital Structure, Company Value

\section{PENDAHULUAN}

Perusahaan yang memiliki daya saing selalu berusaha untuk dapat menghadapi tingkat persaingan bisnis dengan resiko yang muncul dalam proses meningkatkan nilai perusahaan. Timbulnya resiko bersumber dari internal maupun eksternal perusahaan, (Fia, 2016). Kondisi eksternal berkaitan dengan tingkat persaingan antar perusahaan yang sejenis dan kondisi perekonomian yang terjadi dan kondisi internal berkaitan dengan pengelolaan perusahaan utuk keberlangsungan hidup jangka panjang. Setiap perusahaan bertujuan memaksimalkan nilai perusahaan. Hal ini penting bagi perusahaan karena dengan memaksimalkan nilai perusahaan berdampak kemakmuran para pemegang saham. Nilai Perusahaan menggambarkan sumber dana yang dimiliki perusahaan pada periode tertentu (Widhiastuti,2019). Pengukuran nilai perusahaan dapat menggunakan PBV (price book value). Hasil penelitian Rodoni dan Ali (2014:4) menjelaskan bahwa semakin tinggi PBV, menunjukkan keberhasilan perusahaan menciptakan nilai bagi pemegang saham. Nilai perusahaan dapat ditingkatkan melalui berbagai investasi dengan sumber pendanaan yang besar, waktu pengembalian cukup panjang dan resiko yang sebanding dengan keuntungan yang diharapkan. Sumber pendanaan yang berasal dari luar perusahaan menimbulkan beban hutang. Untuk itu pengelolaan terhadap hutang dan resiko, dibutuhkan modal intelektual yang baik agar resiko dan hutang dapat dikelola dengan baik.

Modal intelektual merupakan aset perusahaan yang sangat penting dan bernilai dalam dunia usaha, tetapi aset ini tidak tampak dalam susunan laporan keuangan perusahaan. Modal intelektual yang berkualitas dapat mempengaruhi nilai perusahaan (Mujhtadi, 2013), memperkecil resiko investasi dan juga berperan dalam memanaj hutang yang dimiliki perusahaan. Modal intelektual dapat tercermin dari modal sumber daya manusia, modal structural dan modal relasi (Britto et al, 2014). Risiko investasi adalah besaran atau ukuran dari sebuah ketidakpastian yang menggambarkan variansi imbal hasil dari sebuah investasi (Syahyunan, 2013). resiko investasi timbul karena adanya penyimpangan antara harapan dengan sesungguhnya terjadi. Ukuran risiko investasi menggunakan standar deviasi, sedangkan struktur modal adalah perbandingan antara modal asing dan modal sendiri. Struktur Modal masih berkaitan dengan risiko yang melekat dalam setiap usaha dan cara-cara menentukan struktur modal yang dapat menguntungkan perusahaan. Indicator penilaian struktur modal adalah Debt to Equity Ratio (DER). Hasil penelitian Gayatri dan Mustanda (2012) dan Rizqia, et al. (2013) menunjukkan bahwa struktur modal berpengaruh positif dan signifikan terhadap nilai perusahaan sedangkan menurut hasil penelitian Artini dan Anik (2011) dan Savitri, dkk (2012) menunjukkan bahwa struktur modal berpengaruh tidak signifikan terhadap nilai perusahaan. Berdasarkan penjelasan dan gap penelitian maka

Tujuan penelitian ini adalah untuk mengetahui dan menganalisa pengaruh modal intelektual terhadap nilai perusahaan dan peran modal intelektual dalam memoderasi pengaruh resiko investasi dan struktur modal terhadap nilai perusahaan serta pengaruh resiko investasi dan struktur modal terhadap nilai perusahaan. 


\section{LANDASAN TEORI}

\section{Modal Intelektual}

Pulic (2000) dan Iranmahd, Mohsen et al (2014) mendefinisikan modal intelektual sebagai sumber pengetahuan, informasi, kekayaan intelektual, pengalaman yang digunakan untuk menciptakan kesejahteraan. Metode untuk mengukur modal intelektual mengguanakn VAIC. Model VAIC dikembangkan pertama kali oleh Pulic (1998). Model ini tidak mengukur secara langsung modal intelektual perusahaan tetapai mengukur dari efisiensi nilai tambah sebagai hasil dari kemampuan intelektual perusahaan (Value Added Intellectual Coefficient - VAIC), dan membagi modal intelektual menjadi 3 komponen yaitu: Modal Manusia (Human Capital), Modal Organisasi (Structural Capital) dan Modal Pelanggan (Relational Capital,) jadi VAIC $=\mathrm{HC}+\mathrm{SC}+\mathrm{RC}$. Metode VAIC ini sangat penting bagi perusahaan untuk menciptakan value added (VA). Value added adalah indikator paling objektif untuk menilai keberhasilan dan kemampuan perusahaan dalam penciptaan nilai, (Andriani, dkk, 2014). Nilai diperoleh dari sumber aset berwujud (tangible asssets) dan aset tidak berwujud (intangible assets) yang dimiliki perusahaan.

\section{Risiko Investasi}

Tandelilin (2011) menjelaskan bahwa risiko merupakan perbedaan antara return yang aktual dengan return yang diharapkan. Resiko berdampak pada penurunan kinerja dan nilai perusahaan, untuk itu perlu memahami dan memanaj resiko sebelum investasi diputuskan. Paramitasari (2011) dan Fia (2016) menjelaskan risiko untuk pengambilan keputusan investasi yaitu risiko sistematis dan risiko tidak sistematis. Pengelolaan resiko yang baik dapat meminimalis resiko yang akan timbul dari keputusan yang dibuat.Pengelolaan risiko menjadi perhatian mendasar dalam era global saat ini. Hal ini disebabkan karena pada era global, bisnis dihadapkan pada lingkungan dengan ketidakpastian dan komplekstitas yang sangat tinggi (Aditya dan Naomi, 2017).

\section{Struktur Modal}

Struktur Modal merupakan perimbangan antara total hutang dengan modal yang dimiliki. Menurut Weston dan Brigham (2001:150), Struktur Modal yang optimal merupakan kombinasi antara hutang dan ekuitas yang dapat memaksimalkan harga saham. Brigham dan Houston (2006) menjelaskan bahwa kebijakan struktur modal melibatkan perimbangan (trade off) antara risiko dan tingkat pengembalian. Menurut Prasetya (2014) , Paramitasari (2011) menjelaskan bahwa DER merupakan rasio dari perbandingan antara total hutang perusahaan dengan total ekuitas perusahaan.

\section{Nilai Perusahaan}

Nilai Perusahaan merupakan persepsi masyarakat terhadap perusahaan yang dapat dicerminkan melalui harga saham. Semakin tinggi harga saham, semakin inggi nilai perusahaan karena dengan nilai yang tinggi menunjukkan kemakmuran pemegang saham, menurut Rodoni dan Ali (2014:4) nilai perusahaan dapat diukur dengan Price Book Value (PBV). Hoyt, dkk (2008) melalui penelitiannya meyakini bahwa terdapat hubungan yang positif anatara pengelolaaan resiko terhadap nilai perusahaan yang dapat diukur dengan nilai buku yang diukur dari total aset dan nilai pasar diukur dari jumlah saham yang dimiliki dengan harga per lembarnya. 


\section{Kerangka Pemikiran}

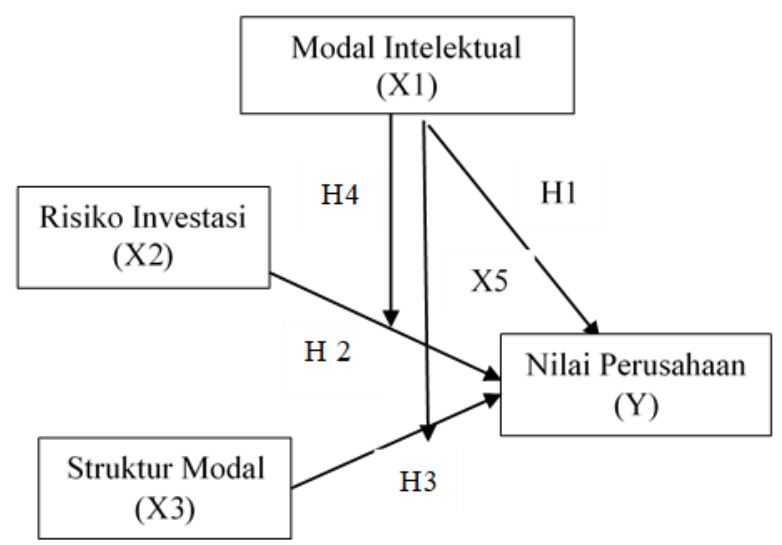

Gambar 1. Model Penelitian

Berdasarkan kerangka tersebut hipotesa yang diambil mempunyai pengaruh yang signifikan dan dapat dijabarkan sebagai berikut:

$\mathbf{H}_{1}$ : Modal intelektual berpengaruh terhadap nilai perusahaan

$\mathbf{H}_{2}$ : Resiko investasi berpengaruh terhadap nilai perusahaan

$\mathbf{H}_{3}$ : Struktur modal berpengaruh terhadap nilai perusahaan

$\mathbf{H}_{4}$ : Modal Intelektual dapat memoderasi pengaruh risiko investasi dengan niai perusahaan

$\mathbf{H}_{5}$ : Modal intelektual dapat memoderasi pengaruh struktur modal dengan nilai perusahaan

\section{METODOLOGI}

Penelitian ini menggunakan data sekunder dan untuk menguji hipotesa menggunakan regresi berganda. Populasi dilakukan pada 12 perusahaan makanan minuman Tbk, di BEI pada tahun 2017 dan 2018. Jenis penelitian menggunakan Explanatory Research, tipe kausal yang berupaya menguji pengaruh variable independen terhadap variable dependen. Variebel idependen adalah modal intelektial, risiko bisnis dan modal structural sedangkan variable independent adalah nilai perusahaan. Teknik pengambilan sampel menggunakan purposive sampling. Sugiyono (2012:117) menjelaskan cara pemilihan sampel menggunakan kriteria tertentu. Kriteria dalam penelitian ini adalah perusahaan telah menerbitkan laporan keuangan secara berturut-tirut dalam 2 tahun, memiliki arus kas yang positif, perusahaan yang membagikan deviden kas selama 2 tahun bertutu-turut dan memilik pertumbuhan aktiva. Berdasarkan kriteria tersebut maka jumlah sampel yang diperoleh sebanyak 12 perusahaan yang dapat dilihat pada table 1. Nama perusahaan adalah:

Tabel 1. Nama Perusahaan

\begin{tabular}{lll}
\hline No & Kode & Nama Perusahaan \\
\hline 1 & ADES & PT. Akasha Wira Internasional Tbk \\
2 & ALTO & PT. Tri Banyan Tirta Tbk \\
3 & BTEK & PT. Campina Ice Cream Indusrty Tbk \\
4 & BUDI & PT. Sariguna Primatirta Tbk \\
5 & CEKA & PT. Wilmar Cahaya Indonesia Tbk \\
6 & DLTA & PT. Delta Djakarta Tbk \\
7 & INDF & PT. Indofood Sukses Makmur Tbk
\end{tabular}




\begin{tabular}{lll}
8 & MLBI & PT. Multi Bintang Indonesia Tbk \\
9 & MYOR & PT. Mayora Indah Tbk \\
10 & ROTI & PT. Nippon Indosari Corpindo Tbk \\
11 & SKLT & PT. Sekar Laut Tbk \\
12 & STTP & PT. Siantar Top Tbk \\
\hline
\end{tabular}

Pengukuran pada penelitian ini:

Modal intelektual menggunakan ukuran VAIC (Value Added Intellectual Coefficient - VAIC) (Pulic.2000 dan Andriyani dkk,2014. VAIC = HC + SC + RC. HC (Human Capital), SC (Structural Capital) dan RC (Relational Capital,). Risiko Investasi (Aditya dan Naomi, 2017).menggunakan standar deviasi. Struktur modal menggunakan DER (Brigham dan Houston, 2006 dan Prsetyo, 2014) merupakan rasio dari perbandingan antara total hutang perusahaan dengan total ekuitas perusahaan. Nilai perusahaan menggunakan Price book value (Prasetya, 2014) merupakan harga pasar per lembar saham dibagi dengan nilai buku per lembar saham.

\section{HASIL DAN PEMBAHASAN}

\section{Analisis Deskriptif}

Tabel 2. Hasil Uji Statistic Deskriptive

\begin{tabular}{|c|c|c|c|c|c|}
\hline & $\mathbf{N}$ & Minimum & Maximum & Mean & Std. Deviation \\
\hline MODAL & 48 & 5.3124 & 832.6680 & 7.496708 & 200.7386962 \\
\hline \multicolumn{6}{|l|}{ INTELEKTUAL } \\
\hline RISIKO INVESTASI & 48 & .7312 & 105.6030 & 1.567488 & 20.8479328 \\
\hline STRUKTUR & 48 & .0074 & 3.6013 & 1.076756 & .6658222 \\
\hline \multicolumn{6}{|l|}{ MODAL } \\
\hline NILAI & 48 & .0530 & 270.8060 & 6.425940 & 86.6779361 \\
\hline \multicolumn{6}{|l|}{ PERUSAHAAN } \\
\hline Valid N (listwise) & 48 & & & & \\
\hline
\end{tabular}

Dari hasil uji statistic descriptive output analisis diatas, menunjukkan bahwa Modal intelektual memiliki rentang nilai dari 5.3124 hingga 832.6680. Nilai terendah dimiliki oleh PT. Mayora Indah Tbk pada triwulan 1 tahun 2017 dan nilai tertinggi dimiliki oleh PT. Indofood Sukses Makmur Tbk pada triwulan 2 tahun 2017. Variabel risiko investasi memiliki rentang nilai dari 0.7312 hingga 105.6030 . Nilai rata-rata risiko investasi 1.5674 dan standar deviasi 20.8479. Nilai terendah dimiliki oleh PT. Delta Djakarta Tbk pada triwulan 1 tahun 2017 dan nilai tertinggi dimiliki oleh PT. Akasha Wira Internasional Tbk pada triwulan 1 tahun 2017.

Variabel struktur modal memiliki rentang nilai dari 0.0074 hingga 3.6013. Nilai rata-rata struktur modal 1.0767 dan standar deviasi 0.6658. Nilai terendah dimiliki oleh PT. Indofood Sukses Makmur Tbk pada triwulan 1 tahun 2018 dan nilai tertinggi dimiliki PT. Multi Bintang Indonesia Tbk pada triwulan 2 tahun 2018. Variabel nilai perusahaan memiliki rentang nilai dari 0.0530 hingga 270.8060 Nilai rata-rata nilai perusahaan 6.4259 dan standar deviasi 86.6779. Nilai terendah dimiliki oleh PT. Nippon Indosari Corpindo Tbk pada triwulan 1 tahun 2018 dan nilai tertinggi dimiliki oleh PT. Multi Bintang Indonesia Tbk pada triwulan 1 tahun 2018. 


\section{Uji Koefisien Determinasi $\left(\mathbf{R}^{2}\right)$}

Berdasarkan hasil uji sebelum adanya variable moderasi modal intelektual (model pertama) adalah:

Tabel 3. Hasil Uji Koefisien Determinasi $\left(\mathbf{R}^{2}\right)$

\begin{tabular}{lllll}
\multicolumn{3}{l}{ Model Summary } \\
\hline Model & R & R Square & Adjusted R Square & Std. Error of the Estimate \\
\hline 1 & $.543^{\text {a }}$ & .294 & .246 & 5.03463 \\
\hline
\end{tabular}

a. Predictors: (Constant), MI, RI, SM

b. Dependent Variable: NP

Sumber: Data diolah, 2020

Berdasarkan table 3 diperoleh nilai koefisien determinasi pada model pertama sebesar 0,246. Hal ini menunjukkan bahwa $24,6 \%$ variable nilai perusahaan dapat dipengaruhi modal intelektual, risiko investasi dan struktur modal, sisanya yaitu sebesar $(100 \%-24,6 \%=75,4 \%)$ dipengaruhi oleh variable diluar variable yang diteliti. Untuk mengetahui besarnya uji $\mathrm{F}$ dan besaran pengaruh dari masing-masing variable yang diteliti dapat dilihat pada table 4 uji F dan 5 untuk uji regresi linier berganda dibawah ini:

Uji F

Tabel 4. Hasil Uji F

\begin{tabular}{lllllll}
\multicolumn{2}{l}{ ANOVA $^{\mathbf{b}}$} \\
\hline \multicolumn{1}{l}{ Model } & Sum of Squares & df & Mean Square & F & Sig. \\
\hline 1 & Regression & 465.473 & 3 & 155.158 & 6.121 & $.001^{\text {a }}$ \\
& Residual & 1115.288 & 44 & 25.347 & & \\
& Total & 1580.761 & 47 & & & \\
\hline
\end{tabular}
a. Predictors: (Constant), MI, RI, SM
b. Dependent Variable: NP
Sumber: Data diolah, 2020

Berdasarkan nilai signifikansi (Sig.) dari output anova diatas, diketahui nilai Sig. sebesar 0,001<0,05. Maka dapat disimpulkan bahwa hipotesis diterima atau dengan kata lain modal intelektual, risiko investasi dan struktur modal secara simultan berpengaruh terhadap nilai perusahaan.

\section{Uji Regresi Linier Berganda}

Tabel 5. Hasil Uji Regresi Linier Berganda

\section{Coefficients $^{\mathrm{a}}$}

\begin{tabular}{lllllll}
\hline \multirow{2}{*}{ Model } & \multicolumn{2}{l}{$\begin{array}{l}\text { Unstandardized } \\
\text { Coefficients }\end{array}$} & \multicolumn{2}{l}{$\begin{array}{l}\text { Standardized } \\
\text { Coefficients }\end{array}$} & \multirow{2}{*}{ t } & Sig. \\
\cline { 2 - 5 } & B & Std. Error & Beta & & \\
\hline 1 & (Constant) & 9.828 & 2.489 & & 3.948 & .000 \\
& MI & .250 & .118 & .282 & 2.121 & .040 \\
& RI & -1.063 & .368 & -.382 & -2.891 & .006 \\
& SM & -2.121 & 2.124 & -.129 & -.999 & .323 \\
\hline
\end{tabular}

a. Dependent Variable: $\mathrm{NP} \quad \mathrm{Ml}=$ modal intelektuan $\mathrm{Rl}=$ resiko investasi $\mathrm{SM}=$ struktur modal Sumber: Data diolah, 2020 
Berdasarkan hasil output pada tabe 5 diatas, persamaan regresi dapat dibuat persamaan $\mathrm{Y}=9,828+$ 0,250 MI-1,063 RI-2,121 SM. Persamaan regresi tersebut menunjukkan bahwa konstanta 9,828 artinya tanpa adanya pengaruh dari variable yang diteliti nilai perusahaan sebesar 9,828. Modal Intelektual memiliki pengaruh sebesar 0,250. Risiko Investasi sebesar -1,063. dan Struktur Modal sebesar -2,121 terhadap nilai perusahaan.

\section{Model Kedua}

\section{Uji Koefisien Determinasi $\left(\mathbf{R}^{2}\right)$}

Berdasarkan hasil uji setelah adanya variable moderasi, maka besarnya $\mathrm{R}$ square dapat dilihat pada tabel 6. dibawah ini:

Tabel 6. Hasil Uji Koefisien Determinasi $\left(\mathbf{R}^{2}\right)$ Moderasi

Model Summary ${ }^{b}$

\begin{tabular}{lllll}
\hline Model & R & R Square & Adjusted R Square & Std. Error of the Estimate \\
\hline 1 & $.566^{\mathrm{a}}$ & .321 & .258 & 4.99655
\end{tabular}

a. Predictors: (Constant), MI, RI, SM, Moderasi RI-MI, Moderasi SM-MI

b. Dependent Variable: NP

Sumber: Data diolah, 2020

Berdasarkan table 6 diatas, diperoleh nilai koefisien determinasi sebesar 0,258. Hal ini menunjukkan bahwa $25,8 \%$ variable nilai perusahaan dapat dijelaskan oleh modal Intelektual dalam memoderasi risiko Investasi dan struktur modal terhadap nilai perusahaan serta risiko investasi dan sruktur modal dalam mempengaruhi nilai perusahaan. Selisih sebesar $0,742(100 \%-25,8 \%=74,2 \%)$ dipengaruhi oleh variable diluar variable yang diteliti. Untuk mengetahui besarnya uji $\mathrm{F}$ dan besaran pengaruh dari masing-masing variable yang diteliti dapat dilihat pada table 7 uji F dan table 8 untuk uji regresi linier berganda dibawah ini:

Uji F

Tabel 7. Hasil Uji F Moderasi

\begin{tabular}{lllllll}
\multicolumn{2}{l}{ ANOVA $^{\mathbf{b}}$} \\
\hline \multicolumn{1}{l}{ Model } & Sum of Squares & df & Mean Square & F & Sig. \\
\hline 1 & Regression & 507.244 & 3 & 126.811 & 5.079 & $.002^{\text {a }}$ \\
& Residual & 1073.518 & 43 & 24.966 & & \\
& Total & 1580.761 & 47 & & & \\
\hline
\end{tabular}

a. Predictors: (Constant), MI, RI, SM, MODERASI MI-RI, MODERASI MI-SM

b. Dependent Variable: NP

Sumber: Data diolah, 2020

Berdasarkan nilai signifikansi (Sig.) dari output anova diatas, diketahui nilai Sig. sebesar 0,002 < 0,05. Maka dapat disimpulkan bahwa hipotesis diterima atau dengan kata lain peran modal intelektual dalam memoderasi risiko investasi dan struktur modal secara simultan berpengaruh terhadap nilai perusahaan. 


\section{Uji-t}

Tabel 8. Hasil Uji Regresi Linier Moderasi

Coefficients $^{\mathrm{a}}$

\begin{tabular}{lllllll}
\hline \multirow{2}{*}{ Model } & \multicolumn{2}{l}{$\begin{array}{l}\text { Unstandardized } \\
\text { Coefficients }\end{array}$} & \multicolumn{2}{l}{$\begin{array}{l}\text { Standardized } \\
\text { Coefficients }\end{array}$} & t & Sig. \\
\cline { 2 - 5 } & B & Std. Error & Beta & & \\
\hline 1 & (Constant) & 9.673 & 2.507 & & 3.858 & .000 \\
& MI & 3.677 & 3.345 & .223 & 1.099 & .278 \\
& RI & -2.177 & .678 & -.781 & -3.211 & .003 \\
& SM & -.021 & 2.722 & -.001 & -.008 & .994 \\
& MODERASI & .401 & .217 & .922 & 1.853 & .071 \\
& MI-RI & & & & & \\
& MODERASI & -.527 & .391 & -.716 & -1.347 & .185 \\
& & & & & \\
\hline
\end{tabular}

a. Dependent Variable: NP MI-RI = Modal Intelektual Resiko Investasi, MI-SM= Modal intelektual struktur modal.

Sumber: Data diolah, 2020

Berdasarkan hasil output diatas, maka model persamaan regresi linier berganda dapat disusun sebagai berikut:

$\mathrm{Y}=9,673+3,677 \mathrm{MI}-2,177 \mathrm{RI}-0,021 \mathrm{SM}+0,401$ Moderasi MI-RI - 0,527 Moderasi MI-SM

Berdasarkan persamaan regresi menunjukkan bahwa nilai konstanta sebesar 9,673 artinya nilai perusahaan tanpa adanya variable yang mempengaruhi maka nilainya sebesar 9,673. Besarnya pengaruh modal Intelektual bepengaruh positif tidak signifikan sebesar 3,677. Resiko investasi berpengaruh negative dan signifikan terhadap nilai perusahaan sebesar -2,177. Struktur modal berpengaruh negatif dan tidak signifikan sebesar -0,021. Untuk variable risiko investasi yang dimoderasi oleh modal intelektual memiliki pengaruh positif dan signifikan sebesar 0,401 dan variable struktur modal yang dimoderasi oleh modal intelektual berpengaruh negative dan tidak signifikan sebesar -0,527.

\section{Pembahasan}

Berdasarkan tabel t sebelum moderasi, maka dapat diketahui $\mathrm{t}$ hitung dan tingkat signifikasi dari variabel independen yang telah diuji. Untuk mencari t tabel yaitu $\mathrm{t}=\mathrm{df} / \mathrm{n}-\mathrm{k}$ maka diketahui hasil $\mathrm{t}$ tabel sebesar 2,015 yang kemudian akan dibandingkan dengan nilai t hitung dari masing-masing variabel independen.

\section{Modal Intelektual terhadap Nilai Perusahaan}

Berdasarkan hasil uji statistik t, diperoleh nilai t hitung $(2,121>2,015)$ dan nilai signifikansi $(0,040<0,05)$. Jadi, dapat disimpulkan bahwa Modal Intelektual berpengaruh positif signifikan terhadap Nilai Perusahaan 0,25. Hal ini menjelaskan bahwa dengan adanya modal intelektual (sumber daya manusia, sumber daya structural dan sumber daya relasi) yang berkualitas dan dikelola dengan baik dapat meningkatkan nilai perusahaan. Hal ini sesuai dengan penelitian Widhiastuti (2018) dan Andriyani dkk (2014). Berdasarkan penjelasan tersebut maka hipotesa diterima. 


\section{Risiko Investasi terhadap Nilai Perusahaan}

Berdasarkan hasil uji statistik t, diperoleh nilai t hitung $(-2,891<2,015)$ dan nilai signifikansi $(0,006<$ $0,05)$. Jadi, dapat disimpulkan bahwa Risiko Investasi berpengaruh negatif dan signifikan terhadap Nilai Perusahaan sebesar -1.065 . Hal ini menunjukkan bahwa semakin tinggi resiko maka nilai perusahaan menjadi menurun. Tandelilin (2011) menjelaskan bahwa resiko akan berbanding lurus dengan pendapatan. Jika resiko tinggi sebaiknya keuntungan yang akan diterima juga tinggi. Hasil penelitian ini sejalan dengan penelitian dari Permanasari (2010). Sedangkan penelitian ini berbeda dengan penelitian yang dilakukan oleh Fia (2016). Berdasarkan penjelasan tersebut maka hipotesa diterima

\section{Struktur Modal terhadap Nilai Perusahaan}

Berdasarkan hasil uji statistik t, diperoleh nilai t hitung $(-0,999<2,015)$ dan nilai signifikansi $(0,323>0,05)$. Jadi, dapat disimpulkan bahwa struktur modal berpengaruh negatif dan tidak signifikan terhadap nilai perusahaan sebesar -2,121. Hal ini menunjukkan bahwa semakin tinggi hutang maka menyebabkan beban perusahaan berupa bunga dan angsuran semakin tinggi dan nilai perusahaan semakin turun. Brigham dan Houston. (2006.) dan penelitain ini sejalan dengan hasil penelitian Artini (2011) yang menjelaskan bahwa struktur modal berpengaruh negative dan tidak signifikan terhadap nilai perusahaan. Berdasarkan penjelasan tersebut maka hipotesa ditolak.

\section{Modal Intelektual dapat Memoderasi Risiko Investasi Terhadap Nilai Perusahaan}

Berdasarka hasil uji $t$, diperoleh nila $t$ hitung lebih kecil dari nilai t tabel $(1,853<2,017)$ dan nilai signifikannya lebih besar dari $5 \%$. $(0.071>0,05)$. Dan besarnya peran modal intelektual dalam memoderasi pengaruh antara risiko investasi dan nilai perusahaan adalah positif dan tidak signifikan sebesar 0.40. Jadi dapat disimpulkan bahwa risiko investasi yang dimoderasi oleh modal Intelektual memiliki pengaruh yang positif cukup besar walaupun tidak signifikan dengan ukuran signifikan $5 \%$ terhadap nilai perusahaan. Berdasarkan penjelasan, diatas maka hipotesanya ditolak. Hal ini menunjukkan bahwa resiko berbanding lurus dengan pendapatan, semakin tinggi risiko maka pendapatan yang diterima juga tinggi. Pendapatan yang besar akan meningkatkan keuntungan perusahaan dan berdampak pula terhadap kenaikan nilai perusahaan. Pernyataan tersebut tidak selalu benar karena dari hasil penelitian tersebut menunjukkan tidak signifikan. Hasil penelitian Bertinetti, dkk (2013) menjelaskan bahwa terdapat relasi yang positif antara nilai perusahaan dengan penerapan manajemen resiko. Memanaj resiko dapat menggunakan modal intelektual yang tersedia.

\section{Peran Modal Intelektual dalam memoderasi Struktur Modal terhadap Nilai Perusahaan}

Berdasarkan hasil uji statistik t, diperoleh nilai t hitung $(-1,347<2,017)$ dan nilai sig $(0.185>0,05)$. Jadi dapat disimpulkan bahwa struktur modal yang dimoderasi oleh modal intelektual berpengaruh negative dan tidak signifikan terhadap nilai perusahaan sebesar -0.527. maka hipotesanya ditolak. Pengaruh negative menunjukkan bahwa semakin tinggi hutang dapat menimbulkan tambahan beban bunga dan angsuran yang menyebabkan turunnya keuntungan dan dampak penurunan nilai perusahaan yang cukup besar yaitu -0.527 . Pernyataan tersebut tidak selalu benar terbukti adanya ketidaksignifikan dengan tingkat sig $5 \%$ karena jika hutang dimanaj dengan baik dengan menggunakan potensi modal intelektual yang tinggi maka beban hutang dapat ditutup dari arus kas yang diterima dari hasil investasi tersebut. 


\section{SIMPULAN}

Berdasarkan hasil analisis yang telah dilakukan dan dibahas sebelumnya untuk menguji Peran Modal Intelektual Dalam Memoderasi Risiko investasi dan Struktur Modal terhadap Nilai Perusahaan, maka dapat disimpulkan sebagai berikut:

1. Hasil penelitian menunjukkan bahwa modal intelektual memiliki pengaruh yang paling besar sebagai variable bebas terhadap nilai perusahaan dibanding variable lain yang diteliti yaitu positif signifikan 0,25 dan jika ada penambahan variable moderasi, peran modal intelektual terhadap nilai perusahaan berpengaruh positif dan tidak siginifikan sebesar 3,677. Hal ini menunjukkan bahwa peran modal intelektual sebagai asset perusahaan memiliki peran yang sangat penting. Hal ini sesuai dengan penelitian Widhiastuti (2019) dan Putra (2012) yang menyatakan bahwa modal intelektual berpengaruh terhadap nilai perusahaan.

2. Hasil penelitian menyatakan bahwa risiko investasi berpengaruh negative dan signifikan terhadap nilai perusahaan. Hal ini menunjukkan bahwa semakin tinggi resiko maka nilai perusahaan menjadi turun. Jika resiko investasi dimoderasi oleh modal intelektual berpengaruh positif dan tidak sgnifikan. Hal ini menunjukkan bahwa resiko investasi yang di manaj dengan baik oleh modal intelektual seperti sumber daya manusia, sumber daya structural dan sumber daya relasi maka resiko menjadi berkurang dan pendapatan meningkat seiring meningkatnya nilai perusahaan. Hal ini sejalan dengan peneltian Aditya (2017).

3. Hasil penelitian menyatakan bahwa struktur modal berpengaruh negative dan tidak signifikan terhadap nilai perusahaan baik sebelum adanya moderasi maupun setelah ada moderasi hal ini menunjukkan bahwa semakin tinggi hutang maka nilai prusahaan semakin turun. Setelah adanya variable moderasi modal intelektual menunjukkan bahwa pernyataan tersebut besarnya nilai ketidaksignifikannya semakin besar, hal ini menunjukkan bahwa dengan adanya moderasi modal intelektual hutang tidak selalu menurunkan nilai perusahaan sepanjang hutang dapat menghasilkan keuntungan yang dapat menutup beban dan angsuran yang ada. Penelitian ini sejalan dengan penelitian Hartini dan Widhiastuti (2017) yang menjelaskna bahwa struktur modal berpengaruh negative dan tidak signifikan terhadap nilai perusahaan dan berbeda dengan hasil penelitian yang berkaitan dengan struktur modal dan modal intelektual (Gayatri, 2012) dan dilakukan oleh Nur, Siyami. (2019) yang meyatakan bahwa struktur modal berpengaruh positif terhadap nilai perushaan.

4. Peran moderasi modal intelektual sebagai variable moderasi, sesuai penelitian Fatchan, A. (2020), menunjukkan bahwa jika dilihat dari R square varibel moderasi ini memiliki nilai yang lebih besar dibanding sebelum adanya moderasi modal intelektual yaitu sebesar 0.258 dengan 0.246 . Hal ini menunjukkan bahwa modal intelektual memiliki peran sebagai variable yang memperkuat pengaruh resiko investasi dan struktur modal terhadap nilai perusahaan. Pernyataan yang menunjukkan bahwa struktur modal berpengaruh negative terhadap nilai perusahaan semakin tidak signifikan.

5.

\section{Saran}

Berdasarkan hasil analisis, pembahasan dan kesimpulan serta keterbatasan yang dilakukan untuk penelitian ini, Adapun saran yang dapat diberikan sebagai berikut:

\section{Bagi perusahaan}

a. Hasil penelitian ini menunjukkan bahwa modal intelektual memiliki pengaruh yang tinggi terhadap nilai perusahaan. Perusahaan sebaiknya mengelola modal intelektual dengan baik sebagai asset perusahaan yang tidak tampak.

b. Hasil penelitian ini menunjukkan bahwa risiko investasi yang tinggi akan menurunkan nilai perusahaan, sebaiknya perusahaan selalu memanaj resiko dengan baik. 
c. Hasil penelitian ini menunjukkan bahwa struktur modal berpengaruh negative terhadap nilai perusahaan. Sebaiknya perusahaan sebelum menggunakan sumber pendanaan dari luar harus dipertimbangkan tentang beban bunga yang timbul, angsuran dan arus kas yang diterima.

d. Hasil penelitian peran modal intelektual sebagai variable moderasi secara keseluruhan menunjukkan bahwa nilai $R$ Square memiliki nilai yang lebih besar dibandingkan sebelum adanya moderasi. Hal ini memperkuat bahwa modal intelektual sangat penting bagi keberlangsungan dan daya saing perusahaan.

\section{Bagi peneliti selanjutnya}

a. Menambah kajian literatur dengan menggunakan variable selain variable yang diteliti yang dapat mempengaruhi nilai perusahaan.

b. Menambah sampel dan periode waktu penelitian.

\section{REFERENSI}

Achyani, F., Trisnawati, R., \& Mulato, F. Y. (2020). Pengaruh Karakteristik Perusahaan Terhadap Nilai Perusahaan Dengan Intellectual Capital Sebagai Variabel Moderasi. JIFA (Journal of Islamic Finance and Accounting), 3(1).

Aditya, O., \& Naomi, P. (2017). Penerapan manajemen risiko perusahaan dan nilai perusahaan di sektor konstruksi dan properti. Esensi: Jurnal Bisnis dan Manajemen, 7(2), 167-180.

Andriani, B., \& Jamaluddin, M. (2014). The Influence of Intellectual Capital Components to Financial Performance and Value of the Firm Registered In Indonesia Stock Exchange. Macrothink Institute, Research In Applied Economics, 6(1) .

Artini, L. G. S., \& Puspaningsih, N. L. A. (2011). Struktur kepemilikan dan struktur modal terhadap kebijakan dividen dan nilai perusahaan. Jurnal Keuangan dan Perbankan, 15(1), 66-75.

Bertinetti, G. S., E. Cavezzali, \& G. Gardenal. (2013).The Effect of The Enterprise Risk Management Implementation on The Frim Value of Europian Companies. Working Paper n. 10/2013, pp. 11-12.

Brigham, E. F., \& Houston, J. F. (2006). Dasar-Dasar Manajemen Keuangan. Jakarta: Salemba Empat.

Britto, D. P., Monetti, E., \& da Rocha Lima Jr, J. (2014). Intellectual capital in tangible intensive firms: the case of Brazilian real estate companies. Journal of Intellectual Capital, 15(2), 333-348.

Gayatri, N. L. P. R., \& Mustanda, I. K. (2013). Pengaruh struktur modal, kebijakan dividen dan keputusan investasi terhadap Nilai perusahaan. E-jurnal Manajemen Universitas Udayana, 3(6).

Hartini, E. F., \& Widhiastuti, S. (2018). Effect of Capital Structure, Size of Company, Working Capital to The Performance of The Company And Its Impact on The Value of The Company. Jurnal Manajemen Kewirausahaan, 14(2), 133-148.

Iranmahd, M., Moeinaddin, M., Shahmoradi, N., \& Heyrani, F. (2014). The effect of intellectual capital on cost of finance and firm value. International Journal of Academic Research in Accounting, Finance and Management Sciences, 4(2), 1-8.

Lestari, F. T., \& Sagoro, E. M. (2016). Pengaruh Risiko Sistematis dan Risiko Tidak Sistematis Terhadap Expected Return Portofolio Optimal. Jurnal Profita: Kajian Ilmu Akuntansi, 4(2). 
Mojtahedi, P. (2013). Intellectual capital accounting and its impact on organizational financial performance: Evidence from Malaysian firms. Journal of Basic and Applied Scientific Research, 3(3), 840-845.

Permanasari, W. I., \& Kawedar, W. (2010). Pengaruh kepemilikan manajemen, kepemilikan institusional, dan Corporate Social Responsibility terhadap nilai perusahaan (Doctoral dissertation, UNIVERSITAS DIPONEGORO).

Pulic, A. (2000). Intellectual Capital: Navigating the New Business Landscape. Macmillan Pres Ltd. London

Putra, I. G. C. (2012). Pengaruh Modal Intelektual Pada Nilai Perusahaan Perbankan yang Go Public di Bursa Efek Indonesia. Jurnal IImiah Akuntansi dan Humanika, 2(1).

Ratih, P. (2011). Pengaruh Risiko Sistematis dan Risiko Tidak Sistematis terhadap Expected Return Portofolio Saham Perusahaan Manufaktur yang Terdaftar di Bursa Efek Indonesia. Jurnal Ekonomi.

Rodoni, A. Ali, A.B., \& Ahmad, B. (2014). Manajemen Keuangan Modern, Mitra Wacana Media. Jakarta.

Savitri, E., Salim, U., \& Thoyib, A. (2012). Variabel Anteseden dari Struktur Modal: Dampaknya terhadap Nilai Perusahaan (Studi pada Perusahaan Manufaktur di Bursa Efek Indonesia). Jurnal Aplikasi Manajemen, 10(1), 85-96.

Siyami, N. (2019). Pengaruh Intellectual Capital, Good Corporate Governance dan Struktur Modal Terhadap Kinerja Keuangan Perusahaan Dengan "Growth Opportunity" sebagai Pemoderasi Studi Empiris pada Perusahaan Perbankan Go Public yang Terdaftar di Bursa Efek Indonesia (BEI). SEGMEN Jurnal Manajemen dan Bisnis, 15(2).

Sugiyono. (2016). Statistik untuk penelitian. Penerbit: ALFABET, Bandung

Tandelilin, E. (2011), Analasis Investasi dan Manajemen Portofolio, BPFE, Yogyakarta

Widhiastuti, S. (2018). Pengaruh Intelijen Bisnis, Modal Intelektual dan Kinerja Perusahaan Terhadap Nilai Perusahaan Yang Dimoderasi Oleh Leverage. Proceeding Manajerial dan Kewirausahaan, 3, 113127.

Widhiastuti, S., \& Nugraha, R. S. (2019). Pengaruh Modal Intelektual, Biaya Promosi, dan Perputaran Persediaan dalam Mempengaruhi Profit Serta Implikasinya Terhadap Nilai Perusahaan. Jurnal Manajemen Kewirausahaan, 15(2), 183-192. 